\title{
Communication
}

Marcelo de Lima

https://orcid.org/0000-0003-3102-1659

Diego Gustavo Diel

[Comunicação]

\section{Identification of equine herpesvirus type 1 as cause of abortion in mares} \section{in Southern Brazil}

[Identificação do herpesvirus equino tipo 1 como causa de abortos em éguas no sul do Brasil]

\author{
P. Estima-Silva ${ }^{1}$, F. Riet-Correa ${ }^{2}$, A.C.B. Coelho ${ }^{1}$, J.V.Z. Echenique ${ }^{1}$, \\ C. Marcolongo-Pereira ${ }^{3}$, M. Lima ${ }^{4}$, D.G. Diel $l^{5}$, A.L. Schild ${ }^{4 *}$ \\ ${ }^{1}$ Programa de pós-graduação - Faculdade de Veterinária - Universidade \\ Federal de Pelotas - (UFPel) Pelotas, RS \\ ${ }^{2}$ Instituto Nacional de Investigación Agropecuaria (INIA) - Estación Experimental \\ La Estanzuela- Colonia del Sacramento, Colonia, Uruguay \\ ${ }^{3}$ Faculdade de Veterinária - Centro Universitário do Espírito Santo (UNESC) - Colatina, ES \\ ${ }^{4}$ Faculdade de Veterinária (FV) - Universidade Federal de Pelotas (UFPel) - Pelotas, RS \\ ${ }^{5}$ South Dakota State University - Brookings, USA
}

Equine herpesvirus type-1 (EHV-1) is classified into the family Herpesviridae, subfamily Alphaherpesvirinae, gênero Varicellovirus (International..., 2018). This virus is a ubiquitous pathogen that affects the horse population worldwide causing epidemic abortion, neonatal death, respiratory disorders and myeloencephalopathy (Schulmann et al., 2015). Infection with this virus may cause a serious economic impact in the horse industry, especially for breeding farms (Gilkerson et al., 1999). In Brazil, serological studies have demonstrated the circulation of EHV-1 in horses (Lara et al., 2010; Diaz et al., 2015). Latency has been demonstrated in both lymphoid and neural tissues and allows the virus to circulate silently in the horse populations (Patel et al., 2005).

Equine herpesvirus-1 abortion is diagnosed by detailed examination of the aborted fetus using a combination of gross findings, histopathology, virus isolation, polymerase chain reaction (PCR), and immunostaining (Reed et al., 2004). Conventionally, these tests have been applied to selected target organs, particularly the liver, lung, thymus and spleen (Easton et al., 2009). The main purpose of this study was to describe and confirm EHV-1 as cause of abortion in southern Brazil.

Recebido em 20 de dezembro de 2017

*Autor para correspondência (corresponding author)

Aceito em 6 de outubro de 2018

E-mail: alschild@terra.com.br
The epidemiological data of each case were obtained from the necropsy submission forms of the Laboratório Regional de Diagnóstico of the Universidade Federal de Pelotas, RS, Brazil (LRD/UFPel). Sections of paraffin embedded tissues were subjected to hematoxylin and eosin staining and samples of the liver, spleen and lungs were processed for immunohistochemical (IHC) analysis using a polyclonal antibody specific to EHV-1 (PAB-ERV - VMRD) and analyzed using a commercial streptavidinalkaline phosphatase kit (LSAB+System-AP, Dako Cytomation, K0689 [Dako Cytomation, 6392 Via Real, Carpinteria, CA, USA]) according to a previous study (Easton et al., 2009). Positive (a previously confirmed EHV-1 case) and negative controls (liver, spleen and lungs from a healthy, EHV-1-free horse) were included. A specific EHV-1 and EHV-4 multiplex nested PCR was performed on DNA extracted from sections of paraffin-embedded tissues by using Quick-DNA FFPE MiniPrep (Zymo Research) according to the protocol provided by the manufacturer (GE Healthcare). PCR conditions and primers were previously described (Ataseven et al., 2009). An aliquot of the product from the first round of amplification was used as template for the second round of PCR. Amplicons specific for EHV-1 (188bp) were visualized after electrophoresis in agarose gel $(1.0 \%)$ stained with Gel Red. After, the PCR 
products were excised from the gel, purified using the Gene JET Gel Extraction Kit (Thermo Scientific) and, subjected to DNA sequencing using both reverse and forward primers (ABI 3700 DNA analyzer). The sequences were trimmed and the homology searches performed with BLAST (Basic Local Alignment Search Tool). DNA extracted from a reference strain of EHV-1 propagated in RK13 cells was used as a positive control.

Four EHV-1 infection outbreaks in thoroughbred mares were identified in the necropsy protocols of the LRD/UFPel. These cases occurred between 1994 and 2012. In the first outbreak, eight out of 16 pregnant mares aborted. Seven abortions occurred between 10 and 11 months of gestation, and one abortion occurred in a 9month-pregnant mare. The mares of this stud farm were not vaccinated against equine rhinopneumonitis. In another outbreak, there were two abortions and one stillbirth out of 35 pregnant mares. In the third outbreak, one abortion of a 9-month old fetus occurred in one mare out of 50 pregnant mares. In the fourth outbreak, one abortion of a 10 months old fetus was recorded in a herd of 50 pregnant mares, which have been vaccinated with a commercial vaccine against rhinopneumonitis annually. No serologic status of the vaccinated animal was available.

In all outbreaks, only formalin-fixed organ samples were received for evaluation at the laboratory. The clinicians described the findings grossly as a diffuse yellow tinge to all tissues and abundant amber fluid in body cavities.

Microscopic evaluations in all cases showed multiple random foci of degeneration and necrosis (Figure 1A) with moderate infiltration by lymphocytes and macrophages in the liver. Several acidophilic nuclear inclusion bodies were also observed in the hepatocytes and Kupffer cells (Figure 1A). Multifocal necrosis was also evident in the spleen along with multiple acidophilic intranuclear inclusion bodies. The lungs exhibited multifocal necrotic foci randomly distributed in the parenchyma and acidophilic intranuclear inclusion bodies were also observed in the epithelia of the bronchioles. Extramedullary hematopoiesis was observed was evident in some less affected areas of the liver.
EHV-1 antigen was detected using IHC staining within the nucleus and cytoplasm of several hepatic cells and leukocytes of the tissue samples from all the cases. Positive IHC staining was associated with necrotic foci in the liver (Figure $1 B)$, lung and in the spleen in all analyzed samples.

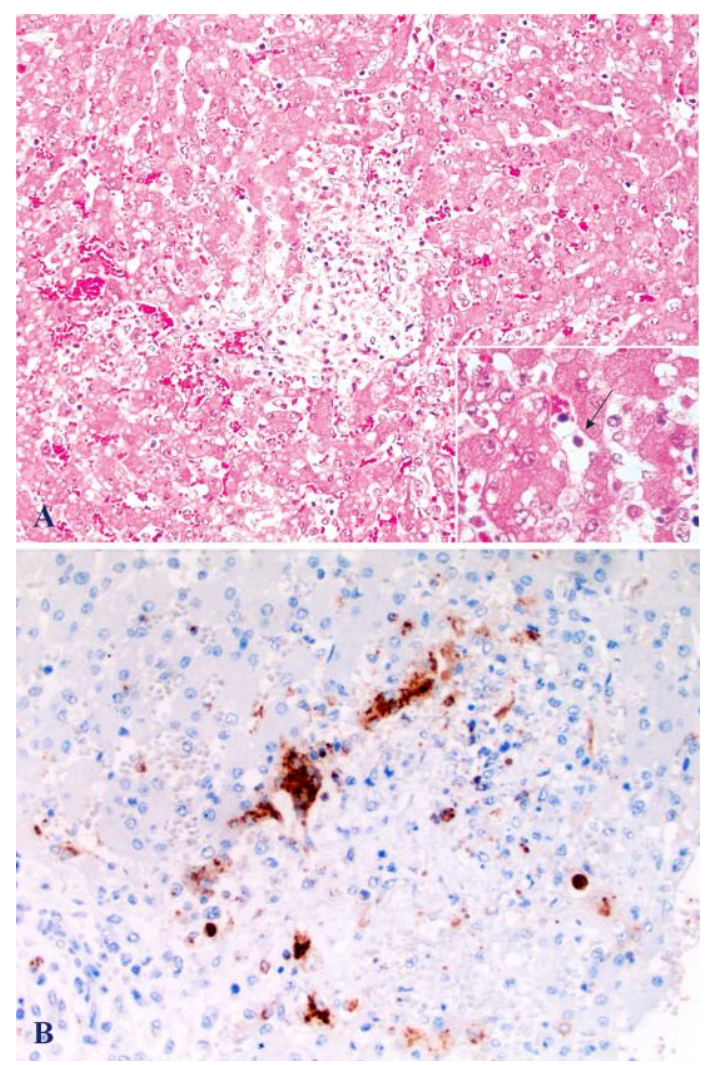

Figure 1. Equine abortion by EHV-1. A. There is a necrotic focus in the hepatic parenchyma and congestion of sinusoids. H.E. Obj. 20x. Inset. Acidophilic nuclear inclusion body is observed in degenerated hepatocyte (arrow). H.E. Obj. 40x. B. Labeling of EHV-1 viral antigen in the hepatocytes of the aborted foal.

$90 \times 137 \mathrm{~mm}(300 \times 300 \mathrm{DPI})$.

The amplification of a specific 188bp amplicon from DNA extracted from two paraffinembedded tissues confirmed the presence of EHV-1 in tissue samples from two aborted fetuses. Additionally, the sequencing of the PCR products and BLAST results obtained with the consensus sequence (100\% identity with multiple gB sequences available in the GenBank) confirmed the presence of EHV-1 DNA in the tissues analyzed. 
EHV-1 abortion was first diagnosed in Southern Brazil in 1994 by isolation of virus associated with the high prevalence of EHV-1 antibodies in the equine population (Weiblen et al., 1994). These authors suggested that abortions due to this virus are more frequent than reported as a consequence of absence of laboratory diagnosis. Several other reports have demonstrated the presence of specific antibodies to EHV-1 in Brazil (Vargas e Weiblen, 1991). However, it was demonstrated in the present study that the prevalence of viral abortion was less frequent in Southern Brazil compared with other causes of equine abortion in the same region. EHV-1 abortion accounted for $3.8 \%$ out of 104 abortion outbreaks diagnosed in this region between 1978 and 2016 (Schild et al., 2017). The low prevalence observed in these cases could be explained, at least partially, by the systematic vaccination of the animals in stud farms.

Abortion outbreaks are described in vaccinated mares from a reproductive center that specializes in the impregnation of mares using artificial insemination and embryo transfer. The authors suggest that broodmare management and improvement of the vaccine efficacy could prevent abortion outbreaks (Barrandeguy et al., 2002). Foote et al. (2006) demonstrate that EHV1 and EHV-4 circulate in vaccinated populations of mares and their unweaned foals. This could explain the occurrence of sporadic abortion in vaccinated animals, which was observed in the present report. The annual vaccination without serological monitoring of mares may also have contributed to the occurrence of the abortion.

Histological lesions observed in the present study were characteristic of abortions by EHV (Schlafer e Miller, 2007). IHC analysis showed the presence of EHV-1 antigen in tissues of aborted fetus. IHC analysis is an important diagnostic tool especially in cases suspected of EHV infection in which specific histopathological changes are not found (Szeredi et al., 2003). In the present study the viral etiology of the abortions outbreaks was confirmed based on the histological lesions along with the detection of antigens of EHV-1 by immunohistochemical analysis. Furthermore, specific EHV-1 DNA was detected (by the multiplex nested-PCR) and confirmed (by nucleotide sequencing and BLAST analysis) on tissue samples of two cases, corroborating the findings of IHC and histological analysis. Taken together, these findings indicated that EHV-1 should be considered in the differential diagnosis of equine abortion in southern Brazil.

Keywords: abortion, equine herpesvirus-1, immunohistochemistry, PCR

\section{RESUMO}

Foi realizado um estudo retrospectivo dos casos suspeitos de aborto por herpesvírus equino observados na região sul do Rio Grande do Sul entre 1978 e 2016. Foram revisados os protocolos de necropsia do Laboratório Regional de Diagnóstico da Faculdade de Veterinária da Universidade Federal de Pelotas resgatando-se os dados epidemiológicos, lesões macroscópicas e histológicas de cada caso. Foram observados dois surtos da enfermidade com prevalência entre $5,7 \%$ e $50 \%$ nos diferentes estabelecimentos, e dois casos individuais. Em todos os casos foram enviados fragmentos de órgãos fetais formolizados. Histologicamente, em todos os casos foram observados focos de necrose no fígado, pulmão e baço e presença de corpúsculos de inclusão acidofílico em hepatócitos, células epiteliais pulmonares e leucócitos. A imuno-histoquímica utilizando anticorpo policlonal comercial para herpesvirus equino-1 (EHV-1) revelou marcação positiva em todos os casos. Além disso, foi extraído DNA dos tecidos emblocados em parafina dos casos e submetidos à técnica de nested-PCR seguida de sequenciamento genômico dos amplicons em duas amostras. Estes achados indicam, que EHV-1 deve ser considerado como diagnóstico diferencial em casos de aborto em equinos no sul do Rio Grande do Sul.

Palavras-chave: aborto, herpesvirus equino-1, imuno-histoquímica, PCR 


\section{REFERENCES}

ATASEVEN, V.S.; DAGALP, S.B.; GUZEL, M. et al. Prevalence of equine herpesvirus-1 and equine herpesvirus-4 infections in equidae species in Turkey as determined by ELISA and multiplex nested PCR. Res. Vet. Sci., v.86, p.339-44, 2009.

BARRANDEGUY, M.E.; LASCOMBES, F.; LLORENTE, J. et al. High case-rate equine herpesvirus-1 abortion outbreak in vaccinated polo mares in Argentina. Equine Vet. Educ., v.14, p.132-135, 2002.

DIAZ, K.A.F.; HUBNER, S.O.; VARGAS, G.D.; FISCHER, G.; LILENBAUM, W.; LIMA, M. Ocorrência de anticorpos contra o herpesvírus equino e vírus da arterite equina em rebanhos equinos do estado do Rio de Janeiro. Ciênc. Anim. Bras., v.16, p.410-418, 2015.

EASTON, C.; FUENTEALBA, N.A.; PAULLIER, C. et al. Immunohistochemical and molecular detection of equine herpesvirus 1 in Uruguay. Rev. Sci. Tech., v.28, p.1085-1090, 2009.

FOOTE, C.E.; LOVE, D.N.; GILKERSON, J.R. et al. EHV-1 and EHV-4 infection in vaccinated mares and their foals. Vet. Immunol. Immunopathol., v.111, p.41-46, 2006.

GILKERSON, J.R.; WHALLEY, J.M.; DRUMMER, H.E. et al. Epidemiological studies of equine herpesvirus 1 (EHV-1) in thoroughbred foals: a review of studies conducted in the Hunter Valley of New South Wales between 1995 and 1997. Vet. Microbiol., v.68, p.15-25, 1999.

INTERNATIONAL Committee on Taxonomy of Viruses. Available in: $<$ https://talk.ictvonline.org/ictv-

reports/ictv_online_report/>. Acessed in: $11 \mathrm{Jul}$. 2018.

LARA, M.C.C.S.H.; TORELLI, C.S.; CUNHA, E.M.S. et al. Inquérito sorológico da infecção por herpesvirus equino no estado de Minas Gerais. Braz. J. Vet. Res. Anim. Sci., v.47, p.352356, 2010.
MARCOLONGO-PEREIRA, C.; ADRIEN, M.L.; LADEIRA, S.R.L. et al. Abortos em equinos na região Sul do Rio Grande do Sul: estudo de 72 casos. Pesqui. Vet. Bras., v.32, p.22-26, 2012.

PATEL, J.R.; HELDENS, J. Equine herpesvirus 1 (EHV-1) and 4 (EHV-4) - epidemiology, disease and immunoprophylaxis: a brief review. Vet. J., v.170, p.14-23, 2005.

REED, S.M.; TORIBIO, R.E. et al. Equine herpesvirus 1 and 4. Vet. Clin. N. Am. Equine Pract., v.20, p.631-642, 2004.

SCHILD A.L.; MARQUES, L.S.; C.; COELHO, A.C.B. et al. Doenças diagnosticadas pelo Laboratório Regional de Diagnóstico no ano 2016. Bol. Labor. Reg. Diag., n.39, p.9-17, 2017.

SCHLAFER, D.H.; MILLER, R.B. Female genital system. In: MAXIE, M.G. (Ed.). Jubb, Kennedy and Palmer's pathology of domestic animals. 5.ed. London: Saunders Elsevier, 2007. v.3, p.429-564.

SCHULMANN, M.L.; BECKER, A.; VAN DER MERWE, B.D. et al. Epidemiology and reproductive outcomes of EHV-1 abortion epizootics in unvaccinated Thoroughbred mares in South Africa. Equine Vet. J., v.47, p.155-159, 2015.

SZEREDI, L.; AUPPERLE, H.; STEIGER, K. Detection of equine Herpesvirus-1 in the fetal membranes of aborted equine fetuses by immunohistochemical and in-situ hybridization techniques. J. Comp. Pathol., v.129, p.147-153, 2003.

VARGAS, A.C.P.; WEIBLEN, R. Prevalência de anticorpos contra o herpesvírus equino tipo 1 em equinos de alguns municípios no estado de Rio Grande do Sul. Hora Vet., v.59, p.5-8, 1991.

WEIBLEN, R.; RABUSKE, M.; REBELATTO, M.C. et al. Abortion due to equine herpesvirus in southern Brazil. Braz. J. Med. Biol. Res., v.27, p.1317-1320, 1994. 